

\title{
CHARACTERIZATION OF SOME PROBIOTIC PROPERTIES OF LACTOBACILLUS GASSERI MA-1 FROM HUMAN MILK
}

\author{
Meltem ASAN-OZUSAGLAM ${ }^{1, *(i)}$, Ayse GUNYAKTI ${ }^{1,2(i D)}$ \\ ${ }^{1}$ Department of Biotechnology and Molecular Biology, Faculty of Science and Letters, Aksaray University, Aksaray, Turkey \\ ${ }^{2}$ Institute of Biotechnology, Ankara University, Ankara, Turkey
}

\begin{abstract}
Human milk is a source of various lactic acid bacteria with the potential of probiotics. The aim of this study was to screen in vitro some probiotic properties of Lactobacillus gasseri MA-1 originated from human milk. The strain showed $\gamma$-hemolytic activity (no hemolytic activity) and susceptibility to Chloramphenicol, Cloxacillin and Penicillin G antibiotics. MA-1 with safety properties also exhibited a good tolerance to $\mathrm{pH} 2$ and $0.3 \%$ bile conditions. L. gasseri MA-1 showed high ability of auto-aggregation (97\%). The co-aggregation activities the strain with five human (Listeria monocytogenes ATCC 7644, Escherichia coli ATCC 35218, Salmonella enteritidis ATCC 13076, Escherichia coli O157:H7 and Salmonella enteritidis RSKK 171) and two fish (Streptococcus agalactiae and Vibrio alginolyticus) originated bacteria varied from $45 \%$ to $57 \%$. The results indicated that, L. gasseri MA-1 strain could be a promising candidate for probiotic products.
\end{abstract}

Keywords: Human breast milk, Tolerance to gastrointestinal condition, Auto-aggregation, Co-aggregation

\section{INTRODUCTION}

Probiotics are non-pathogenic living microorganisms and have a beneficial effect on the host health when given in enough amounts [1]. In the last decade, research on probiotics has progressed significantly and considerable progress has been made in the selection and characterization of certain probiotic strains [2].

Probiotics tend to provide protection against various enteric pathogens in addition to host microflora. Probiotics also improve the host's intestinal barrier property by competition with pathogenic microbiota for adhesion to the gut and improving their colonization [3]. Since the probiotic property is specific to each strain, each strain should be investigated for survival and specific colonization ability in the human gastrointestinal (GI) system. FAO / WHO guidelines also recommend the detection of an antibiotic resistance pattern for species to determinate safety of the strain (GRAS) [1].

The most studied probiotics belong to the genera Lactobacillus and Bifidobacterium, which have health support effects in both humans and animals [4, 5], Enterococcus, Micrococcus and Bifidobacterium [6]. Lactobacillus gasseri found naturally in human milk, gastrointestinal and vaginal system [7-9] and defined as generally regarded as safe (GRAS) microorganism [10].

Probiotic strains should be able to maintain a sufficient number of viability of the host's gastrointestinal tract [11]. In addition, they have to be adherent to human epithelial cells and able to decrase pathogen microorganism adhesion to surfaces. Other important characteristic of probiotics are that they must be safe [12]. Therefore, the present study was aimed to evaluate $L$. gasseri MA-1 for some desirable features in probiotic microorganisms including safety aspects, survival in gastrointestinal conditions and auto-aggregation and co-aggregation abilities. Other features for probiotic evaluation of MA-1 strain have been published in our previous studies $[9,13]$.

*Corresponding Author:meltemozusaglam@gmail.com

Received: 21.10.2019 Published: 30.07.2020 


\section{MATERIALS AND METHODS}

\subsection{Safety Assessment}

L. gasseri MA-1 strain was tested for its antibiotic susceptibility using disc diffusion method [14]. The suspension adjusted to Mc Farland 0.5 was spreaded onto MRS agar medium $(100 \mu \mathrm{L})$. Antibiotic discs (Oxoid) were placed on the surface of inoculated agar with three replicates and then incubated for $24 \mathrm{~h}$ at $37^{\circ} \mathrm{C}$. The diameters of zone surrounding each of the discs were measured by Vernier caliper. The results were presented according to CLSI (Clinical and Laboratory Standards Institute) 2012 standards. The inhibition zone of the strain was considered as susceptible $(\mathrm{S})>20$, intermediate (IR) $\cong 15-19$ and resistant $(\mathrm{R}) \leq 14$.

Hemolytic activity of MA-1 strain was assayed on Colombia agar supplemented with sheep blood $(0.5 \%)$ (OR-BAK, Ankara, Turkey) using the streak-plate method. The plate was then incubated at $37^{\circ} \mathrm{C}$ for $24 \mathrm{~h}$ under anaerobic condition and then evaluated for the hemolytic reaction. Enterococcus faecalis ATCC 29212, E. coli ATCC 35218 and Staphylococcus aureus ATCC 25923 were tested as control.

\subsection{Survival in Gastro Intestinal Conditions}

\subsubsection{Acid tolerance}

The tolerance of the strain to the low $\mathrm{pH}$ environments was evaluated in vitro against $\mathrm{pH} 2$ and 3 in MRS broth at $37^{\circ} \mathrm{C}$. The measurements of spectrophotometric (Beckman Coulter DU 730) were made at $600 \mathrm{~nm}$ for 0,1 and $3 \mathrm{~h}$ of incubation. $0.1 \mathrm{~mL}$ inoculum from each end of the incubation time was then spread onto MRS agar. The inoculated plates were then incubated under anaerobic conditions at $37^{\circ} \mathrm{C}$ for $24 \mathrm{~h}$. Viable cells were counted and calculated in $\log _{10}(\mathrm{CFU} / \mathrm{mL})$ [15].

\subsubsection{Bile tolerance}

The MRS broth containing bile $(0.3 \%$ and $1 \%$, Oxoid) was inoculated with the strain and then incubated for $4 \mathrm{~h}$ at $37^{\circ} \mathrm{C}$. The measurements of spectrophotometric were made at $600 \mathrm{~nm}$ at 0 and $4 \mathrm{~h}$ of incubation twice for each sample. MRS agar media was also inoculated from the test groups after these incubation times and then incubated under anaerobic conditions for $24 \mathrm{~h}$ at $37^{\circ} \mathrm{C}$. The survival cell was counted after 0 and $4 \mathrm{~h}$ and calculated as described acid tolerance assay [16].

\subsubsection{Simulated gastric and pancreatic juice tolerance}

The tolerance of L. gasseri MA-1 to simulate gastric transit was assayed using the simulated gastric solutions containing pepsin ( $3 \mathrm{~g} / \mathrm{L}$, Sigma-Aldrich) at $\mathrm{pH} 2$ and 3 . The gastric solution was inoculated with bacterial suspension adjusted to McFarland 0.5 standard (1\%) and incubated for $3 \mathrm{~h}$ at $37^{\circ} \mathrm{C}$. The cell suspensions were inoculated on MRS agar media at different incubation time intervals $(0$ and $3 \mathrm{~h})$ and then incubated under anaerobic condition for $24 \mathrm{~h}$. The viable cell was counted and expressed as $\log _{10}(\mathrm{CFU} / \mathrm{mL})[17]$.

The simulated small intestine solution was prepared by using pancreatin ( $1 \mathrm{~g} / \mathrm{L}$, Sigma-Aldrich) and bile salt $(0.03 \mathrm{~g} / \mathrm{L}$, Oxoid) to determine the pancreatic tolerance. The pancreatin solution was inoculated with the culture (McFarland 0.5 standard turbidity, $1 \%$ ) and incubated at $37^{\circ} \mathrm{C}$ for $3 \mathrm{~h}$. At 0 and 3 hours of incubated test groups were inoculated onto MRS agar plates and incubated under anaerobic condition for $24 \mathrm{~h}$ at $37^{\circ} \mathrm{C}$. After the incubation, the viable cell count was calculated in the same manner as before described in the tolerance to gastric juice. 


\subsection{Auto-aggregation and Co-aggregation Activities}

Auto-aggregation and co-aggregation activities of the strain were tested according to Xu et al. [18] with some modifications. The cell suspension $\left(0.6 \pm 0.02\right.$ at $\left.\mathrm{OD}_{600} \mathrm{~nm}\right)$ prepared in PBS buffer was incubated at $37^{\circ} \mathrm{C}$ for $4 \mathrm{~h}$ without any moving using a spectrophotometer at OD $600 \mathrm{~nm}$. The percentage of autoaggregation was calculated as follows:

$$
\text { Auto - aggregation } \%=\frac{\mathrm{OD} 1-\mathrm{OD} 2}{\mathrm{OD} 1} \times 100
$$

OD1: Pre-incubation optical density, OD2: Optical density after incubation

The co-aggregation ability of MA-1 strain with various pathogen microorganisms such as $L$. monocytogenes ATCC 7644, E. coli ATCC 35218, E. coli O157:H7, S. enteritidis ATCC 13076, S. enteritidis RSKK 171, S. agalactiae and V. alginolyticus was assayed. Equal volumes ( $2 \mathrm{~mL})$ aliquots of L. gasseri MA-1 culture and pathogenic microorganisms $\left(0.6 \pm 0.02\right.$ at $\left.\mathrm{OD}_{600} \mathrm{~nm}\right)$ were mixed and then incubated at $37^{\circ} \mathrm{C}$ for $4 \mathrm{~h}$. After incubation, the sample $(0.1 \mathrm{~mL})$ was suspended in PBS buffer (3.9 $\mathrm{mL}$ ) and read at $\mathrm{OD}_{600} \mathrm{~nm}$.

The percentage of co-aggregation was calculated as follows:

$$
\text { Co }- \text { aggregation } \%=\frac{(\mathrm{OD} 1+\mathrm{OD} 2)-2(\mathrm{OD} 3)}{(\mathrm{OD} 1+\mathrm{OD} 2)} \times 100
$$

OD1: MA-1 strain optical density (pre-incubation), OD2: Pathogen strain optical density of (preincubation), OD3: Mixed strains optical density (after $4 \mathrm{~h}$ incubation).

\section{RESULT AND DISCUSSION}

\subsection{Safety Properties of MA-1 Strain}

Hemolytic activity and antibiotic resistance profiles of a probiotic candidate are the principal criterion to select safe probiotic strains. One of the most important safety traits for a probiotic strain is the absence of hemolytic activity. In vitro evaluation of hemolytic activity on blood agar media is highly recommended, even for GRAS status bacterial species [12]. L. gasseri MA-1 strain showed $\gamma$-hemolytic activity (no hemolytic activity) (Figure 1).



Figure 1. Hemolytic activity of L. gasseri MA-1

a: E. coli ATCC 35218 ( $\alpha$-hemolytic)

b: S. aureus ATCC 25923 ( $\beta$-hemolytic)

c: E. faecalis ATCC 29212 ( $\gamma$-hemolytic)

${ }^{\mathrm{d}}$ : L. gasseri MA-1 ( $\gamma$-hemolytic) 
Another important requirement to select safe probiotic strain is the lack of antibiotic resistance [19]. Antibiotic susceptibility of MA-1 strain is presented in Table 1. The strain was susceptible to Chloramphenicol, Cloxacillin and Penicillin G and resistant to Amikacin, Nalidixic Acid and Ofloxacin (Table1). Although the species L. gasseri is evaluated as the GRAS status, antibiotic resistance of the probiotic candidate strain must be tested at the strain level. It is required that probiotic candidate strains do not carry any transferrable antibiotic resistance gene that may be transferred to pathogenic microorganisms [20]. Conversely, intrinsic antibiotic resistance can be evaluated beneficial to the host, to keep useful microbiota living in the gastrointestinal system during a treatment of antibiotic [21]. In the reports, the antibiotic resistance of Lactobacillus strains is recognized to be intrinsic or natural because of chromosomally encoded and considering as non-transferable [22]. It is regarded that resistance to aminoglycoside antibiotics, for instance Amikacin, Streptomycin, Kanamycin and Gentamicin is to be intrinsic for the Lactobacillus genus. The resistance occurs due to the lack of cytochrome mediated electron transport mediating drug uptake [22].

Table 1. Antibiotic resistance of L. gasseri MA-1 strain

\begin{tabular}{ccc}
\hline \multirow{2}{*}{ Antibiotic discs } & \multicolumn{2}{c}{ Lactobacillus gasseri MA-1 } \\
\cline { 2 - 3 } & CLSI $^{\mathrm{a}}$ & Mean \pm standard deviation \\
\hline AK $(10 \mu \mathrm{g})$ & $\mathrm{R}$ & $-{ }^{\mathrm{b}}$ \\
\hline C $(10 \boldsymbol{\mu g})$ & $\mathrm{S}$ & $20.72^{\mathrm{c}} \pm 0.91$ \\
\hline OB $(5 \boldsymbol{\mu g})$ & $\mathrm{S}$ & $23.78 \pm 0.85$ \\
\hline NA $(5 \boldsymbol{\mu g})$ & $\mathrm{R}$ & - \\
\hline OFX $(5 \boldsymbol{\mu g})$ & $\mathrm{R}$ & - \\
\hline P $(10 \mu \mathrm{g})$ & $\mathrm{S}$ & $31.69 \pm 2.41$ \\
\hline
\end{tabular}

a: CLSI, Clinical and Laboratory Standards Institute. ${ }^{\text {b}}$ : no inhibition zone ${ }^{\mathrm{c}}$ : inhibition zone diameter. AK: Amikacin, C: Chloramphenicol, OB: Cloxacillin, NA: Nalidixic Acid, OFX: Ofloxacin, P: Penicillin G, R: Resistant, S: Sensitive

\subsection{Tolerance to Gastro Intestinal Conditions}

The survival ability of the strain under highly acidic environments and tolerance to bile salts during transition through the gastrointestinal system are two important key factors to be a probiotic candidate $[23,24]$. The survival rate of MA-1 strain in acidic conditions showed variability (Table 2 ). The survival rate of the strain at $\mathrm{pH} 2$ was found as $148.02 \%$ after the incubation period $(3 \mathrm{~h})$. However, the strain presented lower survival rate at $\mathrm{pH} 3(94.60 \%)$ than $\mathrm{pH} 2$ condition. The strain has never lost its viability at different $\mathrm{pH}$ conditions. Oh et al. [25] reported the survival rate of five L. gasseri strains from infant feces as varying from 97.2 to $100.9 \%$ at $\mathrm{pH} 3$ after $2 \mathrm{~h}$. In the present study, MA-1 strain showed lower viability at $\mathrm{pH} 3(94.60 \%)$ but higher survival rate (148.02\%) at $\mathrm{pH} 2$ after $3 \mathrm{~h}$.

Probiotic strains are exposed to bile fluid after passing the stomach acidic barrier. The survival rate of MA-1 strain was determined as $112.55 \%$ at $0.3 \%$ bile after $4 \mathrm{~h}$ incubation. However, the survival rate slightly reduced $(98.29 \%$ ) with increased concentration (1\%) of bile salts (Table 2). Bile plays a primary role in the specific and nonspecific defense system of the gut and therefore, the bile tolerance is evaluated as an important characteristic of probiotic strains [26]. Bile salt tolerance may be due to the ability of bacteria to deconjugate bile salts, which is dependent on the ability of the bacteria to assimilate cholesterol from intestinal medium [27]. In our previous study, L. gasseri MA-1 strain also showed high anticholesterol activity $(83.41 \%)$ at $0.3 \%$ bile concentration [13]. 
Aşan Özüsağlam and Günyaktı / Eskişehir Technical Univ. J. of Sci. and Tech. C-Life Sci. and Biotech. 9 (2) - 2020

Table 2. Acid and bile resistance of L. gasseri MA-1 strain

\begin{tabular}{|c|c|c|c|c|c|c|c|c|c|c|c|c|c|c|}
\hline \multirow{3}{*}{ Strain } & \multicolumn{8}{|c|}{ Acid Tolerance $\left(\log _{10} \mathrm{Cfu} / \mathrm{mL}\right)$} & \multicolumn{6}{|c|}{ Bile Tolerance $\left(\log _{10} \mathrm{Cfu} / \mathrm{mL}\right)$} \\
\hline & \multicolumn{3}{|c|}{ pH 2} & \multirow[b]{2}{*}{$\begin{array}{l}\text { Survival } \\
\text { rate }(\%)\end{array}$} & \multicolumn{3}{|c|}{ pH 3} & \multirow[b]{2}{*}{$\begin{array}{l}\text { Survival } \\
\text { rate }(\%)\end{array}$} & \multicolumn{2}{|c|}{$0.3 \%$ bile } & \multirow[b]{2}{*}{$\begin{array}{l}\text { Survival } \\
\text { rate }(\%)\end{array}$} & \multicolumn{2}{|c|}{$1 \%$ bile } & \multirow[b]{2}{*}{$\begin{array}{c}\text { Surviv } \\
\text { al rate } \\
(\%)\end{array}$} \\
\hline & $0 . \mathrm{h}$ & $1 . \mathrm{h}$ & 3.h & & $0 . \mathrm{h}$ & 1.h & $3 . \mathrm{h}$ & & $0 . \mathrm{h}$ & 4.h & & $0 . \mathrm{h}$ & 4.h & \\
\hline $\begin{array}{c}\text { L.gasseri } \\
\text { MA-1 }\end{array}$ & $\begin{array}{c}6.8 \\
3\end{array}$ & 8.72 & $\begin{array}{c}10.1 \\
1\end{array}$ & 148.02 & 6.30 & 6.33 & 5.96 & 94.60 & $\begin{array}{c}5.1 \\
8\end{array}$ & 5.83 & 112.55 & $\begin{array}{c}4.6 \\
8\end{array}$ & $\begin{array}{c}4.6 \\
0\end{array}$ & 98.29 \\
\hline
\end{tabular}

Tolerance to pepsin and pancreatin is evaluated as other principal aspects to the determine survival of the strain in the gastrointestinal conditions [28]. L. gasseri MA-1 strain also exhibited good survival ability to the simulated gastric and pancreatic conditions (Table 3). The MA-1 strain showed $83.06 \%$ and $90.53 \%$ survival rate at the simulated gastric juice conditions at $\mathrm{pH} 2$ and 3 after $3 \mathrm{~h}$ incubation. $L$. gasseri MA-1 showed $89.27 \%$ survival rate at pancreatic juice condition after $3 \mathrm{~h}$. The results indicated that $L$. gasseri MA-1 strain could continue viability under gastrointestinal conditions. All the results confirmed that MA-1 strain can be a candidate to be a good probiotic strain.

Table 3. Simulated gastric and pancreatic juice resistance of L. gasseri MA-1

\begin{tabular}{|c|c|c|c|c|c|c|c|c|c|}
\hline \multirow{3}{*}{ Strain } & \multicolumn{6}{|c|}{ Gastric Juice } & \multirow{2}{*}{\multicolumn{2}{|c|}{$\begin{array}{c}\text { Pancreatic juice } \\
\left(\log _{10} \text { Cfu/mL }\right)\end{array}$}} & \multirow{3}{*}{$\begin{array}{l}\text { Survival } \\
\text { rate }(\%)\end{array}$} \\
\hline & \multicolumn{2}{|c|}{$\begin{array}{c}\mathrm{pH} 2.0 \\
\left(\log _{10} \mathrm{Cfu} / \mathrm{mL}\right)\end{array}$} & \multirow{2}{*}{$\begin{array}{l}\text { Survival } \\
\text { rate }(\%)\end{array}$} & \multicolumn{2}{|c|}{$\begin{array}{c}\text { pH 3.0 } \\
\left(\log _{10} \mathrm{Cfu} / \mathrm{mL}\right)\end{array}$} & \multirow{2}{*}{$\begin{array}{l}\text { Survival } \\
\text { rate }(\%)\end{array}$} & & & \\
\hline & 0.h & 3.h & & 0.h & 3.h & & 0.h & 3.h & \\
\hline $\begin{array}{l}\text { L.gasseri } \\
\text { MA-1 }\end{array}$ & 9.86 & 8.19 & 83.06 & 8.66 & 7.84 & 90.53 & 8.67 & 7.74 & 89.27 \\
\hline
\end{tabular}

\subsection{Auto-aggregation and Co-aggregation Activities}

The auto-aggregation and co-aggregation activities of a probiotic candidate strain are primary since auto-aggregation is a relation with adhesion to epithelial cells [29], while co-aggregation states a defensive barrier against pathogenic microorganism colonization [30, 31]. The defensive barrier does not allow pathogen colonization in the human gut [32]. L. gasseri MA-1 showed good auto-aggregation ability (97\%) (Table 4). The coaggregation activity of MA-1 strain with five human (L. monocytogenes ATCC 7644, E. coli ATCC 35218, E. coli O157:H7, S. enteritidis ATCC 13076 and S. enteritidis RSKK 171 ) and two fish (S. agalactiae and V. alginolyticus) originated bacteria ranged from $45 \%$ to $57 \%$ (Table 4). Pino et al. [33] indicated the rate of auto-aggregation and co-aggregation with E. coli 555 of three vaginal $L$. gasseri strains (F5, W14 and W18) as 6.21-12.23\% and 6.35-14.18\%. L.gasseri MA-1 with high aggregation abilities may be a good barrier to pathogens microorganisms.

Table 4. Auto-aggregation and co-aggregation activities of L. gasseri MA-1

\begin{tabular}{|c|c|c|c|c|c|c|c|c|}
\hline \multirow{3}{*}{$\begin{array}{c}\text { L. } \\
\text { gasseri } \\
\text { MA-1 }\end{array}$} & \multirow[b]{2}{*}{$\begin{array}{c}\text { Autoaggregation } \\
(\%)\end{array}$} & \multicolumn{7}{|c|}{ Coaggregation (\%) } \\
\hline & & $\begin{array}{c}L . \\
\text { monocytogen } \\
\text { es ATCC } \\
7644\end{array}$ & $\begin{array}{l}\text { E. coli } \\
\text { ATCC } \\
35218\end{array}$ & $\begin{array}{l}\text { E. coli } \\
\text { O157:H7 }\end{array}$ & $\begin{array}{l}\text { S. enteritidis } \\
\text { ATCC } 13076\end{array}$ & $\begin{array}{l}\text { S. enteritidis } \\
\text { RSKK } 171\end{array}$ & $\begin{array}{c}S . \\
\text { agalactiae }\end{array}$ & $\begin{array}{c}V . \\
\text { alginol } \\
\text { yticus }\end{array}$ \\
\hline & 97 & 53 & 56 & 57 & 53 & 45 & 51 & 51 \\
\hline
\end{tabular}




\section{CONCLUSION}

L.gasseri MA-1 isolated from human milk was studied to evaluate its potential probiotic properties. MA-1 strain exhibited good resistance to gastrointestinal system conditions with high survival rate. The strain with high auto-aggregation and co-aggregation activities can be a defensive barrier against pathogenic microorganism colonization. L.gasseri MA-1 also showed safety aspects. Therefore, $L$. gasseri MA-1 can be evaluated as a potential bioactive ingredient for food and pharmaceutical industries.

\section{REFERENCES}

[1] FAO/WHO. Guidelines for the evaluation of probiotics in food. Geneva: Food and Agriculture Organization of the United Nations and World Health Organization Working Group Report, 2002. Accessed in ftp://ftp.fao.org/es/esn/food/wgreport2.pdf. January 12th, 2016.

[2] Kerry RG, Patrab JK, Goudac S, Parkb Y, Shind H-S, Das G. Benefaction of probiotics for human health: A review. J Food Drug Anal 2018; 26: 927-939.

[3] Rao SC, Athalye-Jape GK, Deshpande GC, Simmer KN, Patole SK. Probiotic supplementation and late-onset sepsisin preterm infants: a meta-analysis. Pediatrics 2016; 137:1e16.

[4] Soccol CR, Vandenberghe LP de S., Spier MR, Medeiros ABP, Yamaguishi CT, De Dea Lindner J, Pandey A, Thomaz-Soccol V. The potential of probiotics: a review. Food Technol Biotech 2010; 48: 413-434.

[5] Di Gioia D, Biavati B. Probiotics and Prebiotics in Animal Health and Food Safety: Conclusive Remarks and Future Perspectives.In: Di Gioia D., Biavati B. (eds) Probiotics and Prebiotics in Animal Health and Food Safety, Springer, Cham, 2018.

[6] Pe'rez-Cano FJ, Dong H, Yaqoob P. In vitro immunomodulatory activity of Lactobacillus fermentum CECT5716 and Lactobacillus salivarius CECT5713: Two probiotic strains isolated from human breast milk. Immunobiology 2010; 215: 996-1004.

[7] Francl AL, Thongaram T, Miller MJ. The PTS transporters of Lactobacillus gasseri ATCC 33323. BMC Microbiology 2010; 10(1): 77.

[8] Singroha G, Mishra, SK, Malik RK. Isolation and characterization of potential probiotic Lactobacillus gasseri strains isolated from different sources. Int J Fermented Foods 2017; 6(1): 71-83.

[9] Gunyakti A, Asan-Ozusaglam M. Lactobacillus gasseri from human milk with probiotic potential and some technological properties. LWT - Food Science and Technology, 2019; 109: 261-269.

[10] Stoeker L., Nordone S, Gunderson S, Zhang L, Kajikawa A, LaVoy A, Miller M, Klaenhammer TR, Dean GA. (2011). Assessment of Lactobacillus gasseri as a candidate oral vaccine vector. Clinical and Vaccine Immunology, 18(11), 1834-1844.

[11] Ljungh A, Wadström T. Lactic acid bacteria as probiotics. Curr Issues Intest Microbiol 2006; 7 : 73-89.PMID:16875422

[12] FAO/WHO, 2002.Joint FAO/WHO Working Group Report on Drafting Guidelines for the Evaluation of Probiotics in Food London, Ontario, Canada, April 30 and May 1, 2002 
Aşan Özüsağlam and Günyaktı / Eskişehir Technical Univ. J. of Sci. and Tech. C-Life Sci. and Biotech. 9 (2) - 2020

[13] Gunyakti A, Asan-Ozusaglam M. Investigation of the potential use of Lactobacillus gasseri originated from human breast milk as food additive. LWT - Food Science and Technology 2018; 93: 613-619.

[14] Sharma P, Tomar SK, Sangwan V, Goswami P, Singh R. Antibiotic resistance of Lactobacillus sp. isolated from commercial probiotic preparations. J Food Saf 2016; 36(1): 38-51.

[15] Zoral S. İnsan kaynaklı Lactobacillus spp. suşlarının probiyotik özelliklerinin belirlenmesi. MSc thesis, University of Ahi Evran, Kırşehir, Turkey, 2013.

[16] Tokatlı M. Identification of lactic acid bacteria isolated from pickles in Ankara Çubuk region, determination of their technological and functional properties and their potential for using as a starter culture, $\mathrm{PhD}$ thesis, University of Ankara, Ankara, Turkey, 2013.

[17] Yürümez E. Probiotics properties of some lactic acid bacteria isolated from faeces samples. MSc thesis, University of Ankara, Ankara, Turkey, 2011.

[18] Xu H, Jeong HS, Lee HY, Ahn J. Assessment of cell surface properties and adhesion potential of selected probiotic strains. Letters in Applied Microbiology 2009; 49(4): 434-442.

[19] Oh YJ, Jung DS. Evaluation of probiotic properties of Lactobacillus and Pediococcus strains isolated from Omegisool, a traditionally fermented millet alcoholic beverage in Korea. LWT Food Sci Technol 2015; 63: 437-444. 10.1016/j.lwt.2015.03.005.

[20] Curragh HJ, Collins MA. High levels of spontaneous drug resistance in Lactobacillus. J Appl Microbiol 1992; 73: 31-36.

[21] Charteris WP, Kelly PM, Morelli L, Collins JK. Antibiotic susceptibility of potentially probiotic Lactobacillus species. J Food Prot 1998; 61: 1636-1643. doi: 10.4315/0362-028X-61.12.1636

[22] Danielsen M, Wind A. Susceptibility of Lactobacillus spp. to antimicrobial agents. Int J Food Microbiol 2003; 82(1): 1-11.

[23] Ayyash M, Abushelaibi A., Al-Mahadin S., Enan M., El-Tarabily K., Shah N. In-vitro investigation into probiotic characterisation of Streptococcus and Enterococcus isolated from camel milk. LWT Food Sci. Technol. 2018; 87: 478-487. 10.1016/j.lwt.2017.09.019.

[24] Kandylis P, Pissaridi K, Bekatorou A, Kanellaki M, Koutinas AA. Dairy and non-dairy probiotic beverages. Curr Opin Food Sci 2016; 7: 58-63. 10.1016/j.cofs.2015.11.012.

[25] Oh NS, Joung JY, Lee JY, Kim Y. Probiotic and anti-inflammatory potential of Lactobacillus rhamnosus 4B15 and Lactobacillus gasseri 4M13 isolated from infant feces. PLoSONE 2018; 13(2):e0192021. https://doi.org/10.1371/journal.pone.0192021

[26] Argyri AA, Zoumpopoulou G, Karatzas KAG, Tsakalidou E, Nychas GJE, Panagou EZ, Tassou CC. Selection of potential probiotic lactic acid bacteria from fermented olives by in vitro tests. Food Microbiol 2013; 33:282-291.

[27] Baick SC, Kim CH. Assessment of characteristics and functional properties of Lactobacillus species isolated from kimchi for dairy use. Korean J Food Sci An 2015; 35(3): 339-349. 
[28] FAO/WHO. Probiotics in food. Health and nutritional properties and guidelines for evaluation. FAO Food and Nutrition Paper 85. FAO, Rome, Italy, 2006.

[29] Collado MC, Meriluoto J, Salminen S. Adhesion and aggregation properties of probiotic and pathogen strains.Eur Food Res Technol 2008; 226: 1065-1073. 10.1007/s00217-007-0632-x

[30] Abushelaibi A, Al-Mahadin S, El-Tarabily K, Shah NP, Ayyash M. Characterization of potential probiotic lactic acid bacteria isolated from camel milk. LWT Food Sci Technol 2017; 79: 316325.

[31] Kos B, Šušković J, Vuković S, Šimpraga M, Frece J, Matošić S. Adhesion and aggregation ability of probiotic strain Lactobacillus acidophilus M92. J Appl Microbiol 2003; 94: 981-987. 10.1046/j.1365-2672.2003.01915.x.

[32] Vidhyasagar V, Jeevaratnam K. Evaluation of Pediococcus pentosaceus strains isolated from Idly batter for probiotic properties in vitro. J Funct Foods 2013; 5: 235-243. 10.1016/j.jff.2012.10.012.

[33] Pino A, Bartolo E, Caggia C, Cianci A, Randazzo CL. Detection of vaginal lactobacilli as probiotic candidates. Scientific Reports 2019; 9:3355 https://doi.org/10.1038/s41598-019-40304-3 